SINET: Ethiop. J. Sci., 21(1):67-80, 1998

(C) Faculty of Science, Addis Ababa University, 1998

ISSN: 0379-2897

\title{
EVALUATION OF NEW ISOLATES OF LACTIC ACID BACTERIA AS A STARTER FOR CULTURED MILK PRODUCTION
}

\author{
Fekadu Beyene ${ }^{1}$, J. Narvhus ${ }^{2}$ and R.K. Abrahamsen ${ }^{2}$ \\ ${ }^{1}$ Awassa College of Agriculture, PO Box 5, Awassa, Ethiopia \\ ${ }^{2}$ Department of Food Science, Agricultural University of Norway \\ Box 5036, N-1432, Às, Norway
}

\begin{abstract}
Strains of lactic acid bacteria belonging to Lactococcus lactis species were isolated from naturally fermented milk products in Ethiopia and evaluated as starter cultures noting for milk coagulation time, organic acid metabolism, production of volatile aroma compounds (acetaldehyde, diacetyl and acetoin). Ten strains of Lactococcus lactis were selected for further evaluation as a single strain starter culture for the production of cultured milk. The strains of Lactococcus lactis varied significantly in production of volatile compounds and metabolism of organic acids. The sensory properties of the cultured milk also differed when the different strains were used as a starter culture. Although flavour scores and concentration of individual volatile compounds showed little correlation, variations in sensory attributes of the products suggested that use of promising strains among the new isolates as a starter could enhance production of stable and good quality cultured milk. Further evaluation of these strains, as mixed cultures under different conditions is required to determine strains that complement each other for the desired metabolic property.
\end{abstract}

Key words/phrases: Cultured milk, Lactococcus lactis, organic acids, sensory property, volatile aroma compounds

\section{INTRODUCTION}

The ability of milk to coagulate is one of the determinant factors for both the quality and quantity of fermented milk products. It depends in part on the chemical composition (Gibson, 1989; Sutton, 1989; Davoli, 1990; Macheboeuf .et al., 1993). However, the starter culture has an important role in determining 
the quality and stability of the fermented milk. Lactic fermentation of foods is a widely accepted method of preservation, which may also impart desirable sensory and nutritional properties to the fermented products. In many instances, the use of microorganisms to process foods requires less energy than conventional processing (Steinkraus, 1983; Cooke et al., 1987).

Natural lactic fermentation through inoculum recycling has been employed by rural women in Ethiopia for the processing and preservation of various food items and drinks (Steinkraus, 1983) including various dairy products (O'Mahony and Peter, 1987; Mogessie Ashenafi, 1990; Fekadu Beyene, 1994). This timehonoured technology could be improved through appropriate scientific experimentation such as isolation, identification, evaluation, selection and use of cultures based on the specific metabolic functions of the particular organism or organisms involved. Such innovation could enable the producers to improve their product's quality, shelf life, and thus its marketability. Evaluation of strains, in particular with respect to the relationship between metabolites and organoleptic attributes, is a primary important step. The information so gained can be used for further research regarding these organisms and the development of traditional products.

The pre-treatment of milk (Mogessie Ashenafi and Fekadu Beyene, 1994) and the type of micro-flora influence development of microorganisms and the microbial groups constituting the flora during storage of milk. Nout et al. (1989) reported that recycling of inoculum achieves a natural selection of lactic acid bacteria (LAB) in fermenting mixtures of cereals, tubers, legumes and water. Strains of LAB that have survived, and are, therefore, the results of, natural selection in a food system would be much more beneficially utilized if examined in a systematic way for a given product under a given set of conditions.

In this paper, the evaluation of some isolates of $L A B$ as a single strain starter cultures for the production of cultured milk are reported. The physico-chemical and sensory properties of the cultured milk as influenced by the starter culture are also described. 


\section{MATERIALS AND METHODS}

\section{Selection of the isolates}

Strains of lactic acid bacteria isolated from naturally fermented milk products (butter milk, cottage cheese and butter) from three different villages in southern Ethiopia (Fekadu Beyene, 1994), were used in this study. The products were sampled randomly among the traditional products produced on farms and the best ones were selected based on organoleptic evaluation of the products.

\section{Identification of the species}

Actively growing cultures in broth were centrifuged and resuspended in 1/4 strength ringer's solution before inoculation of tests. Critical growth temperatures at 10,15 and $45^{\circ} \mathrm{C}$ (Schleifer, 1987), salt tolerance with the basal medium (Lactose $0.5 \%$, Tryptone $0.5 \%$ and Meat extract $0.5 \%$; $\mathrm{pH} 7.2$ ) containing $0,2,4$ and $6 \% \mathrm{NaCl}$, production of ammonia from arginine using arginine broth (Peptone $0.5 \%$, Yeast extract $0.25 \%, \mathrm{~K}_{2} \mathrm{HPO}_{4} 0.2 \%$, Glucose

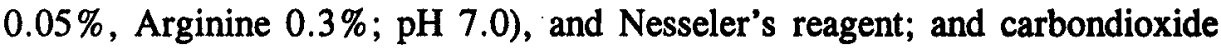
production from glucose in Gibson's milk (Litmus milk 800 ml., Glucose 55 $\mathrm{g}$, Nutrient agar $200 \mathrm{ml}$, Tomato juice $100 \mathrm{ml}$, Yeast extract $2.8 \mathrm{~g}, 1 \mathrm{~N} \mathrm{NaOH}$; pH 7.0) (Gibson and Abd-el-Malek, 1945) were evaluated following standard procedures. Sugar fermentation tests were performed in sterile microtiter plates with flat-bottomed wells.

Cultures of Lactococcus lactis (25 strains) isolated using standard methods (Richardson, 1985) from the selected products and identified using their production of volatile compounds and organic acid metabolism as determined by Head Space Gas Chromatography, and High Performance Liquid Chromatography, respectively, were used in this experiment. A total of 25 single strain cultures capable of reducing the pH of milk to below 4.6 within $24 \mathrm{hrs}$ at $1 \%$ inoculation were used in preliminary experiments. However, strains found to have similar biochemical properties, and which had been isolated from the same product were excluded during the further part of the evaluation.

Organoleptic evaluation of the cultured wholemilk, by two panels of four people each, was used as preliminary screening test. Cultures producing off-flavours and/or an average sensory score of $<3.0$ by both panels were rejected. The 
remaining cultures of Lactococcus (10) were inoculated as pure starter cultures and evaluated for fermentation properties in whole milk.

\section{Preparation of the milk and inoculation}

Pasteurized $\left(72^{\circ} \mathrm{C} / 15 \mathrm{sec}\right.$.) whole milk ( $3.8 \%$ fat) was homogenized at 200 $\mathrm{kp}(\mathrm{cm})^{-2}$ (atmosphere) at $60^{\circ} \mathrm{C}$ and then further heat treated at $90^{\circ} \mathrm{C}$ for 15 min. The milk was cooled $\left(21^{\circ} \mathrm{C}\right)$ and aseptically poured into sterile one litter glass jars, inoculated with $1 \%$ starter cultures and incubated at $30^{\circ} \mathrm{C}$ for 20 hrs. The starter culture was prepared $\left(1 \%\right.$ inoculum) in autoclaved $\left(121^{\circ} \mathrm{C} / 5\right.$ min.) milk $20 \mathrm{hrs}$ before use under similar growth conditions.

\section{Sensory evaluation of the products}

Two panels of four judges each tested cultured milks. Appearance, consistency and flavour were judged, using a scale from one to five, with five points as best. The judges in panel 1 comprised European staff at the Department of Food Science, Agricultural University of Norway (AUN). Panel 2 comprised Ethiopian students at the AUN who had experience of fermented milk products in Ethiopia. The panel had become acquainted with these products during preliminary sessions. Judges were instructed to cleanse their palate between samples by rinsing with cold water.

All fermented milks were evaluated for surface appearance before stirring the coagulum, noting for free cream, free whey, shrunken curd, slimy, and surface discoloration. The evaluation of the consistency or texture was based on sensory observation after stirring the product with an electrical hand-mixer with one cream whipper for $30 \mathrm{sec}$. graininess, ropiness, too firmness and too weakness of the curd were evaluated. The flavour was also evaluated after stirring the coagulum. The samples were tested after 6 hours of cold storage between 6 and $10^{\circ} \mathrm{C}$.

\section{Determination of $\mathbf{p H}$}

The $\mathrm{pH}$ of the fermented milk was determined by a digital pH-meter (Orion Research Model, 701 A/Digital Ionalyzer; Cambridge, Massachusetts, USA) with Orion Electrode (Orion RWU13, 9102SC, Cambridge, Massachusetts, USA). 


\section{Measurement of volatile compounds and organic acids}

Head Space Gas Chromatography (HSGC) and High Pressure Liquid Chromatography (HPLC) were used, respectively, to determine the volatile aroma compounds and organic acid content of the fermented milk as described previously (Fekadu Beyene, 1994). For volatile determination, GC with automatic head space sampler, DANI-HSS 3950, (DANI S.P.A, I-20052 Monza (MI), Italy), connected to a Carlo Erba HRGC 5300 Mega gas chromatograph (Carlo Erba Strumentazione, 120110 Milan, Italy), equipped with a flame ionization detector and capillary column [Chrompak CP SIL 5CB $25 \mathrm{~m} \times 0.53$ $\mathrm{mm}$ id with a 5 micron phase film thickness (Chrompak International B. V., 4330 Ea Middelburg, The Netherlands)] was used.

Flow of the carrier gas nitrogen was adjusted to $3.4 \mathrm{ml}$ per minute. The GC oven temperature used was $53^{\circ} \mathrm{C}(1 \mathrm{~min}),. 70^{\circ} \mathrm{C}\left(2 \mathrm{~min}\right.$.), and $130^{\circ} \mathrm{C}(2$ min.). The rate of temperature increase between these temperatures was 15 and $20^{\circ} \mathrm{C}$ per minute, respectively. The injector and detector temperatyres were maintained at 180 and $120^{\circ} \mathrm{C}$, respectively. Integrated peak areas, calculated by a Shimadzu CR-3A Chromatopac integrator (Shimadzu Corporation, Kyoto, Japan) were used for compound quantification, using external standard calibration. Compounds were identified by their retention times compared to analytical grade standard compounds.

Organic acid analysis was carried by HPLC. Samples were analyzed using a Perkin-Elmer HPLC consisting of automatic sampler (ISS-100), series 4 pump system, UV detector $(210 \mathrm{~nm})$ (LC-95). Detector response was monitored by Maxima 820 chromatography work station (Waters Associates, Dynamic solutions division of Millipore, 2355, California). Compounds were identified according to their retention times and quantified by external standard calibration. Organic acids in extracted samples were separated on an Aminex HPX87H column (Bio Rad Labs. Richmond, CA) using a microguard cation $\mathbf{H}$ guard column. Sulphuric acid $(9 \mathrm{mMol})$ was used as eluant at $0.4 \mathrm{ml}$ per minute and the column was held at $45^{\circ} \mathrm{C}$.

Before stirring the coagulum, samples of the fermented milk were measured into the head space vial and test tube for GC and HPLC analyses, respectively. 


\section{Assessment of physical characteristics}

For the analysis of the firmness of the coagulum before stirring, a Brookfield viscometer, (Brookfield Synchro-Lectric Viscometer, Model RVT, Brookfield Engineering Laboratories, Stoughton, Massachusetts, USA), placed on a Brookfield helipath stand (Helipath stand, Model C, Brookfield Engineering Laboratories, Stoughton, Massachusetts, USA) was used (Holmen and Abrahamsen, 1977). The spindle TF, length 0.43 inches, and 6 rotations per minute was employed, and the reading was made at 30 seconds. A SMRviscosimeter (Tip No. 5) was used for the determination of the viscosity after stirring of the sample (Holmen and Abrahamsen, 1977).

\section{Statistical analysis}

The experimental data, replicated three times in each test, were analyzed using the Statgraphics program (Statistical Graphics Corporation, STSC Inc. Maryland, USA). One-way analysis of variance was employed to evaluate the significance of differences between cultures of Lactococcus lactis on the test attributes, concentrations of organic acids and volatile compounds in the cultured milk. Means were compared at $\mathrm{p}=0.05$ when $\mathrm{F}$ values were significant, using the Tukey's HSD test (O'Mahony, 1986). Correlation coefficients were calculated and compared at $\mathrm{p}=0.01$ and 0.05 . Selection of the strains was based on both the sensory scores and analytical results of the components.

\section{RESULTS AND DISCUSSION}

Strains of LAB evaluated for their potential as a starter culture based on the sensory attributes and final $\mathrm{pH}$ of the cultured milk were selected. Cultures with above-average flavour and consistency score by both panel were chosen as the most promising ones for use as a single strain starter culture in the production of cultured milk. These cultures produced products characterized with final $\mathrm{pH}$ range of 4.34 to 4.44 . Some products evaluated were equally accepted by both panels for their flavour and consistency. The Ethiopian judges showed less preference for products having smooth and uniform texture unlike the traditional Ethiopian fermented milk. The smooth and uniform texture results due to homogenization (Hiller and Lyster, 1979) and heat treatment of the milk (Holmen and Abrahamsen, 1977). 
Flavour scores (Table 1) differed significantly between the products as evaluated by both panels. Lactococcus strains (Lcll-16, Lcll-107 and Lcll-162) produced products of highest flavour score when evaluated by European panel. However, the Ethiopian panel preferred Lcll-16, Lcll-153 and Lcll-110 compared to the rest of the cultures, although the latter (Lcll-110) produced product least preferred by the European panel.

Table 1. Sensory scores of cultured milk produced using different strains of Lactococcus lactis strains isolated from Ethiopian fermented milk.

\begin{tabular}{|c|c|c|c|c|}
\hline \multirow[t]{2}{*}{ Cultures } & \multicolumn{2}{|c|}{ Flavour score } & \multicolumn{2}{|c|}{ Consistency score } \\
\hline & Panel 1 & Panel 2 & Panel 1 & Panel 2 \\
\hline Lcll-16 & $4.05(0.05)^{i}$ & $4.00(0.00)^{c}$ & $4.30(0.10)^{\mathrm{a}}$ & $3.70(0.10)^{\mathrm{ab}}$ \\
\hline Lcll-61 & $3.45(0.05)^{b}$ & $3.75(0.05)^{\mathrm{abc}}$ & $4.10(0.10)^{\mathrm{ad}}$ & $3.85(0.05)^{\mathrm{abc}}$ \\
\hline Lcll-107 & $4.05(0.05)^{c}$ & $3.35(0.05)^{\mathrm{ath}}$ & $4.20(0.05)^{\mathrm{a}}$ & $3.70(0.10)^{\mathrm{ab}}$ \\
\hline Lcll-1 10 & $3.05(0.05)^{\mathrm{a}}$ & $4.00(0.20)^{\mathrm{e}}$ & $3.90(0.30)^{a}$ & $3.90(0.10)^{\mathrm{ahcc}}$ \\
\hline Lcll-148 & $3.25(0.15)^{\mathrm{ab}}$ & $3.30(0.30)^{\mathrm{ab}}$ & $3.75(0.15)^{\mathrm{a}}$ & $3.50(0.10)^{a}$ \\
\hline Lcll-153 & $3.60(0.00)^{\mathrm{b}}$ & $3.95(0.05)^{\mathrm{hx}}$ & $4.45(0.05)^{\mathrm{a}}$ & $4.35(0.15)^{\mathrm{c}}$ \\
\hline Lcll-162 & $4.05(0.05)^{\mathrm{c}}$ & $3.55(0.05)^{\mathrm{atc}}$ & $4.00(0.10)^{\mathrm{a}}$ & $3.70(0.10)^{\mathrm{ab}}$ \\
\hline Lcll-175 & $3.50(0.10)^{b}$ & $3.15(0.05)^{\mathrm{a}}$ & $3.90(0.00)^{a}$ & $3.45(0.05)^{\mathrm{a}}$ \\
\hline Lcll-244 & $3.60(0.05)^{\mathrm{b}}$ & $3.25(0.05)^{a}$ & $4.45(0.05)^{a}$ & $4.05(0.05)^{\mathrm{tc}}$ \\
\hline Lcll-265 & $3.35(0.05)^{\mathrm{ahb}}$ & $3.50(0.00)^{\mathrm{aht}}$ & $4.10(0.10)^{\mathrm{a}}$ & $4.05(0.05)^{\mathrm{hc}}$ \\
\hline
\end{tabular}

atr, Different letters in the same column indicate the presence of significant difference; Panel 1, European judges; Panel 2, Ethiopian judges; Standard errors are given in parenthesis.

Consistency scores did not differ significantly as evaluated by the European panel (Table 1), but significant variation was found in the scores given by the Ethiopian panel. The consistency of products produced using cultures of Lcll61, Lcll-110, Lcll-153, Lcll-244 and Lcll-265 were shown to be preferred to the other products produced by the remaining cultures as evaluated by the Ethiopian panel (Table 2). 
Table 2. Concentration (ppm) of some organic acids and volatile compounds in cultured milk produced using different strains of Lactococcus lactis isolated from Ethiopian fermented milk products.

\begin{tabular}{|c|c|c|c|c|c|}
\hline Cultures & Formic acid & Orotic acid & Acetaldehyde & Diacetyl & Acetoin \\
\hline Lcll-16 & $104(2)^{d}$ & $74(2)^{e}$ & $3.6(0.2)^{\mathrm{cd}}$ & $0.22(0.02)^{\mathrm{a}}$ & $9(1.2)^{\mathrm{ab}}$ \\
\hline Lcll-61 & $96(4)^{\mathrm{cd}}$ & $56(92)^{c d}$ & $4.0(0.1)^{d}$ & $0.00(0.00)^{2}$ & $0(0.0)^{2}$ \\
\hline Lcll-107 & $84(4)^{\mathrm{bc}}$ & $54(0)^{b c d}$ & $1.7(0.1)^{\mathrm{ab}}$ & $1.15(0.15)^{\mathrm{b}}$ & $30(1.5)^{\mathrm{hc}}$ \\
\hline Lcll-110 & $202(4)^{f}$ & $44(1)^{\mathrm{bc}}$ & $0.8(0.1)^{\mathrm{a}}$ & $0.60(0.10)^{\mathrm{ab}}$ & $15(1.0)^{\mathrm{abc}}$ \\
\hline Lcll-148 & $52(2)^{a}$ & $42(2)^{b}$ & $3.4(0.4)^{\mathrm{cd}}$ & $1.25(0.35)^{b}$ & $35(12.0)^{c}$ \\
\hline Lcll-153, & $96(2)^{\mathrm{cd}}$ & $56(2)^{\mathrm{cd}}$ & $1.6(0.1)^{\mathrm{ab}}$ & $0.25(0.05)^{\mathrm{a}}$ & $8(1.8)^{a}$ \\
\hline Lcll-162 & $108(7)^{d}$ & $62(2)^{d e}$ & $1.9(0.1)^{\mathrm{b}}$ & $0.00(0.00)^{\mathrm{a}}$ & $0(0.0)^{\mathrm{a}}$ \\
\hline Lcll-175 & $61(2)^{a}$ & $30(2)^{a}$ & $3.6(0.4)^{c d}$ & $0.00(0.00)^{\mathrm{a}}$ & $0(0.0)^{\mathrm{a}}$ \\
\hline Lcll-244 & $129(2)^{e}$ & $52(2)^{\mathrm{hed}}$ & $2.6(0.1)^{\mathrm{hx}}$ & $0.00(0.00)^{\mathrm{a}}$ & $0(0.0)^{a}$ \\
\hline Lcll-265 & $69(2)^{\mathrm{ab}}$ & $54(4)^{b c d}$ & $1.9(0.1)^{\mathrm{b}}$ & $0.20(0.02)^{\mathrm{a}}$ & $8(0.4)^{2}$ \\
\hline
\end{tabular}

abodef, Different letters in the same column indicate the presence of significant difference; Standard errors are given in parenthesis.

The concentrations of organic acids in cultured milk produced using different strains of Lactococcus lactis are presented in Table 2 and 3. Significant variations were observed in organic acid concentration of the cultured milk produced. Although milk is known to contain various organic acids, variations in concentration of these acids in cultured milk treated in similar manner could be attributed to the activities of starter cultures.

Concentration of some volatile compounds in the cultured milk is presented in Table 2. Variations in production of volatile compounds was significant among the various cultures of Lactococcus studied (Table 2). Diacetyl concentration of cultures of Lcll-107 and Lcll-148 was significantly higher than most of the cultures evaluated, although the values observed were much lower than those reported for diacetyl producing strains of LAB (Ulberth and Kneifel, 1992). Acetoin content also exhibited the same trend as the diacetyl content with the highest concentration shown in these cultures. 
Table 3. Concentration (ppm) of organic acids in cultured milk produced using different strains of Lactococcus lactis isolated from Ethiopian fermented, milk products.

\begin{tabular}{lllll}
\hline Cultures & Citric acid & Lactic acid & Succinic acid & Pyruvic acid \\
\hline Lcll-16 & $2292(18)^{\mathrm{c}}$ & $7132(82)^{\mathrm{cf}}$ & $143(9)^{\mathrm{cd}}$ & $29(3)^{\mathrm{bc}}$ \\
Lcll-61 & $2080(26)^{\mathrm{bc}}$ & $6242(220)^{\mathrm{cd}}$ & $190(10)^{\mathrm{d}}$ & $30(1)^{\mathrm{bc}}$ \\
Lcll-107 & $1732(50)^{\mathrm{ab}}$ & $6754(48)^{\mathrm{def}}$ & $166(49)^{\mathrm{cd}}$ & $50(2)^{\mathrm{d}}$ \\
Lcll-110 & $2260(70)^{\mathrm{c}}$ & $5496(232)^{\mathrm{bc}}$ & $46(5)^{\mathrm{b}}$ & $70(2)^{\mathrm{c}}$ \\
Lcll-148 & $2120(178)^{\mathrm{bc}}$ & $5103(66)^{\mathrm{ab}}$ & $30(1)^{\mathrm{a}}$ & $28(1)^{\mathrm{bc}}$ \\
Lcll-153 & $2174(98)^{\mathrm{bc}}$ & $7264(134)^{\mathrm{ef}}$ & $81(2)^{\mathrm{abc}}$ & $34(1)^{\mathrm{cb}}$ \\
Lcll-162 & $2277(41)^{\mathrm{c}}$ & $6497(38)^{\mathrm{de}}$ & $0(0)^{\mathrm{a}}$ & $26(2)^{\mathrm{a}}$ \\
Lcll-175 & $1426(68)^{\mathrm{a}}$ & $4314(62)^{\mathrm{a}}$ & $129(1)^{\mathrm{bcd}}$ & $14(2)^{\mathrm{a}}$ \\
Lcll-244 & $2250(20)^{\mathrm{c}}$ & $7396(39)^{\mathrm{f}}$ & $218(2)^{\mathrm{d}}$ & $36(1)^{\mathrm{c}}$ \\
Lcll-265 & $2232(94)^{\mathrm{c}}$ & $7532(276)^{\mathrm{f}}$ & $498(10)^{\mathrm{e}}$ & $14(1)^{\mathrm{a}}$ \\
\hline
\end{tabular}

abcdet, Different letters in the same column indicate the presence of significant differences; Standard errors of the mean are given in parenthesis.

The physical characteristics of the cultured milk produced using the single strain starter culture of Lactococcus lactis are given in Table 4. The differences in gel firmness and viscosity of the cultured milk produced using the different strains of Lactococcus lactis was significant $(\mathrm{p}<0.05)$. Viscosity was significantly higher in products with greater gel strength. Lcll-265 produced cultured milk with maximum gel firmness, while the most viscous products were produced with cultures of Lcll-244 as well. The consistency scores (Table 1) of the cultured milk produced using these two strains were noted to be among the preferred ones.

The $\mathrm{pH}$ of the final product is given in Table 4. For most cultures evaluated the difference in $\mathrm{pH}$ of the final product was not significant. The lowest $\mathrm{pH}$ was observed in cultures (Lcll-153) of preferred flavour score, while the highest was in cultures (Lcll-148) of lower flavour score. 
Table 4. Physical characteristics and pH of cultured milk produced using different strains of Lactococcus lactis isolated from naturally fermented milk products in Ethiopia.

\begin{tabular}{llll}
\hline Lactococcus lactis strains & $\begin{array}{l}\text { Gel firmness' } \\
\text { (Pascal-seconds) }\end{array}$ & $\begin{array}{l}\text { Viscosity } \\
(\text { Seconds) }\end{array}$ & pH \\
\hline Lcll-16 & $54(2)^{\mathrm{a}}$ & $56(3)^{\mathrm{d}}$ & $4.38(0.04)^{\mathrm{ab}}$ \\
Lcll-61 & $66(1)^{\mathrm{c}}$ & $78(2)^{\mathrm{c}}$ & $4.44(0.00)^{\mathrm{ab}}$ \\
Lcll-107 & $68(3)^{\mathrm{c}}$ & $75(1)^{\mathrm{e}}$ & $4.36(0.20)^{\mathrm{ab}}$ \\
Lcll-110 & $50(2)^{\mathrm{a}}$ & $40(3)^{\mathrm{bc}}$ & $4.44(0.10)^{\mathrm{ab}}$ \\
Lcll-148 & $56(1)^{\mathrm{ab}}$ & $29(2)^{\mathrm{ab}}$ & $4.48(0.02)^{\mathrm{b}}$ \\
Lcll-153 & $67(1)^{\mathrm{c}}$ & $72(2)^{\mathrm{e}}$ & $4.26(0.04)^{\mathrm{a}}$ \\
Lcll-162 & $52(0)^{\mathrm{a}}$ & $44(1)^{\mathrm{c}}$ & $4.41(0.01)^{\mathrm{ab}}$ \\
Lcll-175 & $53(1)^{\mathrm{a}}$ & $28(1)^{\mathrm{a}}$ & $4.42(0.00)^{\mathrm{ab}}$ \\
Lcll-244 & $64(1)^{\mathrm{bc}}$ & $104(1)^{\mathrm{f}}$ & $4.32(0.00)^{\mathrm{ab}}$ \\
Lcll-265 $^{\mathrm{a}}$ & $79(2)^{\mathrm{d}}$ & $76(2)^{\mathrm{c}}$ & $4.32(0.02)^{\mathrm{ab}}$ \\
\hline
\end{tabular}

wocdef, Different letters in the same column indicate the presence of significant difference.

', Brookfield viscometer with spindle TF at 30 seconds; ${ }^{2}$, SMR viscosimeter, time in seconds; higher values indicate greater firmness and viscosity. Standard errors are given in parenthesis. Average of duplicate determinations and values less than 0.1 were labelled 0 .

Correlation between gel firmness and viscosity $(r=0.80 ; p<0.01)$ was highly significant. It can also be noted that flavour and consistency scores were significantly $(p<0.05)$ correlated when evaluated by both the European panel $(r=0.51)$ and Ethiopian panel $(r=0.69)$. Although it is difficult to correlate sensory parameters with analytical data, many food analysts (Ulberth and Kneifel, 1992) have encouraged substitution of sensory analysis by instrumental methods. Rash (1990) reported that compositional elements influence the flavour of cultured milk. However, Lindsay et al. (1965) reported that the average diacetyl: acetaldehyde ratio of $4: 1$ is found with fully flavoured cultured milk products. In this study, the recorded diacetyl concentration is much lower than reported in the literature for diacetyl producing strains of LAB (Ulberth and Kneifel, 1992), perhaps due to reduction of diacetyl produced due to longer incubation time $(20 \mathrm{hrs}$.$) at higher temperature \left(30^{\circ} \mathrm{C}\right)$. 
Correlation between the concentrations of some organic acids was also noted. Orotic and lactic acid $(r=0.54)$ and uric acid and lactic acid $(r=0.53)$ concentrations were positively correlated. There was also positive correlation $(r=0.54)$ between pyruvic acid and formic acid concentration in the cultured milks.

Consistency evaluations between the two panels were highly correlated $(0.77$; $\mathrm{p}<0.01$ ) although the flavour ratings were not. None of the individual volatile compounds evaluated showed significant correlations with sensory flavour scores by either groups.

One of the main problems in cultured milk production is maintaining the desired texture. Unlike cheese, where whey is drained off, cultured milk must retain the whey within a matrix of casein micelles. Even though this could be achieved by increasing the total solids of the milk to $16-17 \%$ (w/v), alternatives to increasing total solids are the use of polymer producing variants (Toba $e t$ al., 1991) of the starter culture which can produce polysaccharides with texturegiving qualities. In the current study some cultures of Lactococcus lactis were shown to produce cultured milk of higher viscosity than others as evaluated by both panels. Such strains could be a good raw material for future experiment. However, the reason why some strains (for instance, Lcll-251) that produced a rather viscous product were found to have low flavour score need further examination.

Some strains of mesophilic LAB were reported to produce polysaccharide. For instance, Toba et al. (1991) reported production of a capsular polysaccharide by a strain of Lactococcus lactis spp. cremoris isolated from the swedish "lăngfil". The polysaccharide was shown to contain rhamnose, glucose, galactose and glycerol.

Optimum balance of flavour and consistency could be attained through careful study of such strains in mixed culture to determine which and how polymer producing strain and those responsible for flavour compounds complement each other. Strains evaluated as single strain starter cultures should be further examined as mixed culture for optimum balance of the metabolites and sensory property of the cultured milk. 


\section{CONCLUSIONS}

It is concluded that Lcll-16, Lcll-153 and Lcll-110 cultures were the most preferred by the Ethiopian panel and could be used for cultured milk production destined for Ethiopian consumers. Concentrations of the individual volatile compounds showed less direct relationship with the flavour scores of the products. Isolated strains of Lactococcus lactis were shown to have utilized citrate with greater production of volatile compounds. Selection of cultures of $\mathrm{LAB}$ for a given product flavour and consistency need to take account of the target groups' preference. Further evaluation of cultures for stability of important characteristics using single and mixed cultures need to be done.

\section{ACKNOWLEDGMENTS}

We are grateful to the judges who spared their time and evaluated the products, the technical expertise provided by Ms Kari Thorvaldsen during analysis of the samples with Head Space Gas Chromatography (HSGC) and High Performance Liquid Chromatography (HPLC). Finally, we would like to thank Noragric for providing the necessary funding and the Department of Food Science for provision of facilities needed for the experiment. The inspiration and invaluable help of Dr Trygve Berg deserves special mention.

\section{REFERENCES}

1. Cooke, R.D., Twiddy, D.R. and Reilly, P.J.A. (1987). Lactic acid fermentation as a low-cost means of food preservation in tropical countries. FEMS Microbiology Reviews 46:369-379.

2. Davoli, R. (1990). The effect of milk protein polymorphisms on milk components and cheese-producing ability. Journal of Dairy Science 73:241-255.

3. Fekadu Beyene (1994). Present situation and future aspects of milk production, milk handling and processing of dairy products in southern Ethiopia. PhD Dissertation, Agricultural University of Norway, AaS, Norway.

4. Gibson, J.P. (1989). Altering milk composition through genetic selection. Journal of Dairy Science 72:2815-2825. 
5. Gibson, T. and Abd-el-Malek, Y. (1945). The formation of carbondioxide by lactic acid bacteria and Bacillus licheniformis and a cultural method of detecting the process. Journal of Dairy Research 14:35-41.

6. Hiller, R.M. and Lyster, R.L.J. (1979). Whey protein denaturations in heated milk and cheese whey. Journal of Dairy Research 46:95-102.

7. Holmen, T.B. and Abrahamsen, R.K. (1977). Heat treatment, homogenization and incubation of milk for production of kefir, of various fat levels. Sonderdruck aus Nordeuropaische Molkerei-zeitschrift, Nr. 10.

8. Lindsay, R.C., Day, E.A. and Sandine, W.E. (1965). Identification of volatile flavour components of buttermilk, Journal of Dairy Science 48:1566.

9. Macheboeuf, D., Coulon, J.B. and D'hour, P. (1993). Effect of breed, protein genetic variants and feeding on cows' milk coagulation properties. Journal of Dairy Research 60:43-54.

10. Mogessie Ashenafi and Fekadu Beyene (1994). Microbial load, microflora and keeping quality of raw and pasteurized milk from a dairy farm. Bull. Anim. Prod. Afr. 42:55-59.

11. Mogessie Ashenafi. (1990). Effect of curd cooking temperature on the microbiological quality of Ayib, a traditional Ethiopian cottage cheese. World Journal of Microbiology \& Biotechnology 6:159-162.

12. Nout, M.J.R., Rombouts, F.M. and Havellar, A. (1989). Effect of accelerated natural lactic fermentation of infant food ingredients on some pathogenic microorganisms. International Journal of Food Microbiology 8:351-361.

13. O'Mahony, F. and Peters, J. (1987). Options for smallholder milk processing. World Animal Review. No. 62. pp. 16-30.

14. O'Mahony, M. (1986). Sensory Evaluation of Food. Statistical Methods and Procedures. Marcel Dekker, Inc. New York, USA, pp. 153-169.

15. Rash, K. (1990). Compositional elements affecting flavour of cultured dairy foods. Journal of Dairy Science 73:3651.

16. Richardson, G.H. (1985). Standard Methods for the examination of dairy products. 15th edition. American Public Health Association, Washington, D.C.

17. Schleifer, K.H. (1987). Recent changes in the taxonomy of lactic acid bacteria. FEMS Microbiology Reviews 46:201-203.

18. Steinkraus, K.H. (ed.) (1983). Handbook of indigenous fermented foods. Microbiological Series, Vol. 9, Marcel Dekker, Inc. New York. 
19. Sutton, J.D. (1989). Altering milk composition by feeding. Journal of Dairy Science 72:2801-2814.

20. Toba, T., Kotani, T. and Adachi, S. (1991). Capsular polysaccharide of a slime forming Lactococcus lactis subsp. cremoris LAPT 3001 isolated from Swedish fermented milk "Lảngfil". International Journal of Food Microbiology 12:167-172.

21. Ulberth, F. and Kneifel, W. (1992). Aroma profiles and sensory properties of yogurt and yogurt-related products. II. Classification of starter cultures by means of cluster analysis. Milchwissenschaft 47(7):432-434. 